\title{
Јавно доступне библиографије истраживача Србије - стање и перспективе
}

\author{
Биљана Албахари \\ Народна библиотека Србије \\ albaharib@gmail.com
}

\begin{abstract}
Сажетак
Библиографије научних радника у Србији вредан су извор информација о домаћој научној продукцији. Поред тога, оне играју и важну улогу у систему вредновања научних резултата појединаца, пројектних тимова и научних установа. У Србији тренутно не постоји јединствена платформа која би омогућила јавни и потпуни увид у библиографске податке о публикацијама активних научника.

У раду се презентује историјат библиографског праћења научноистраживачког рада у Републици Србији. Представљене су старије библиографске базе и савремени електронски сервиси у којима су реферисани радови истраживача из Србије. Анализом предности и недостатака ових извора дошло се до закључка да у библиотекама Србије постоје различите библиографске базе које међусобно нису повезане.

Решења овог проблема могу се тражити у укључивању свих библиотека у E-CRIS систем, увођењу обавезе за научне раднике да креирају и одржавају ORCID профиле, или успостављању мреже институционалних репозиторијума и националног агрегатора, чиме би се истовремено решили проблеми отвореног приступа научним публикацијама насталим у оквиру домаћих научних пројеката и јавно доступних библиографија научника.
\end{abstract}

Кључне речи: научни радници, Србија, библиографије, електронске базе података и услуга, E-CRIS, дигитални репозиторијуми, ORCID

\section{Ко чини научну заједницу у Србији}

Научноистраживачка делатност регулисана је законом као делатност од посебног значаја за свеукупни развој Републике Србије и, заједно са високим образовањем, главни је чинилац и покретач привредног и друштвеног развоја и саставни је део међународног, научног, образовног и културног простора. Ову делатност чини систематски и стваралачки рад на откривању нових знања која подижу општи цивилизацијски ниво друштва и која се могу користити у свим областима друштвеног развоја. ${ }^{1}$ Да би се ови циљеви остварили, потребно је пратити резултате рада свих научних радника који своја истраживања обављају у научноистраживачким организацијама, институтима и на факултетима. Праћење је потребно не само због дисеминације резултата њиховог рада, него и због тога што ти резултати морају бити видљиви јавности јер се финансирају јавним средствима која им додељује ресорно министарство.

У Републици Србији Министарство просвете, науке и технолошког развоја финансира 119 акредитованих факултета и универзитета, 15 акредитованих центара изузетних вредности и 63 акредитована института. Институти су разврстани на научне и истраживачко-развојне, а у оквиру ове поделе постоји и подела према научним областима истраживања и то на: друштвене, хуманистичке, техничко-технолошке, природно-математичке, медицинске, биотехничке и

Министарство просвете, науке и технолошког развоја републике Србије, „Закон о научно-истраживачкој делатности”, Сл. іласник PC бр. 110 (2005), 50 (2006) - испр., 18 (2010) и 112 (2015), чланови 2, 3 и 4, http://www.mpn.gov.rs/wp-content/uploads/2015/09/ Zakon-o-NID-iz-Paragrafa-sl-gl.-112-iz-2015-preciscen-tekst.pdf_(преузето 26. 10. 2016). 
комбиноване науке. ${ }^{2}$ у 2016. години у Србији је евидентирано око 12.500 истраживача. Нешто више од једне трећине ради у научноистраживачким институцијама, а мање од две трећине на факултетима у високом школству. ${ }^{3}$

\section{Ко прати и прикупља библиографске податке о радовима истраживача}

Према Закону о научноистраживачкој делатности, свака научноистраживачка организација треба да има библиотеку или документациони центар. ${ }^{4}$ Један од најважнијих задатака тих библиотека јесте прикупљање и евидентирање текуће научне продукције научника ангажованих на пројектима који се реализују у научноистраживачким организацијама и њихова дисеминација. Важну улогу у томе има и израда библиографија. Велики број библиотека није у могућности да оствари ову улогу. ${ }^{5}$ У неким институтима, којих је нажалост мало, а у којима су препознати значај и улога библиотека, библиотекари су посредно укључени у научни рад и имају значајну улогу у уређивању, архивирању, одржавању и промовисању библиографија научних и стручних радова истраживача. У највећем броју случајева институтске библиотеке не прикупљају текућу продукцију запослених истраживача зато што та обавеза не постоји, неки научни радници не желе да своје радове доставе библиотеци, библиотеке немају одговарајуће програме или базе података у којима би архивирале радове, а често не постоји ни иницијатива библиотекара.

Увођење обавезе да научни радници библиотеци организације у којој су запослени достављају све публикације које су објавили неминовно би довело до низа активности које воде ка решавању проблема израде библиографија научних радника. Могућа решења укључују придруживање свих библиотека научноистраживачких организација систему COBISS.SR и унос библиографских података у E-CRIS ${ }^{6}$ или успостаљање система јавно доступних институционалних репозиторијума отвореног приступа и националног агрегатора који би из њих прикупљао податке.

\footnotetext{
2 Министарство просвете, науке и технолошког развоја, "Списак акредитованих института", http://www.mpn.gov.rs/wp-content/ uploads/2015/08/Akreditovani-instituti-sredjeno-cir-12-1.pdf (преузето 20. 10. 2016).

${ }^{3}$ Нажалост, на веб-апликацији Министарства просвете, науке и технолошког развоја није могуће наћи податак о броју истраживача. Такође, ни из извештаја Републичког завода за статистику из 2016. године (http://webrzs.stat.gov.rs/WebSite/repository/documents/00/02/28/92/18_Nauka_i_kultura.pdf (преузето 10. 3. 2017)) није могуће утврдити њихов тачан број, те се стога ауторка овог рада позива на публикацију Националног савета за научни и технолошки развој из 2014. године „Наука у Србији 2010-2013", http://rodos.edu.rs/wp-content/uploads/2014/12/Knjiga-Nauka-u-Srbiji-2010-2013.pdf (преузето 26. 10. 2016).

${ }_{4}^{4}$ Више о делатности библиотека научноистраживачких институција и установа видети у Биљана Миленковић-Вуковић и Мили-

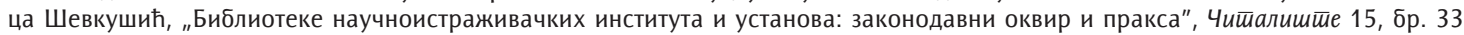
(2016): 18-29.

${ }^{5}$ Национални савет за научни и технолошки развој 2006. године донео је Правилник о вредновању научноистраживачког рада и поступку акредитације научноистраживачких организација. У том Правилнику, између осталог, један од услова је и постојање научно-информативне документације или библиотечко-информационог центра, али овај услов није прецизно дефинисан. Уколико би се поштовали Закон о библиотечко-информационој делатности и пратећи стандарди, требало би да у нашој земљи постоје бар 63 библиотеке у оквиру научноистраживачких организација. У пракси се показало да неки институти, акредитовани у складу са поменутим Правилником, само формално имају регистровану библиотеку и библиотечко особље које није стручно оспособљено за обављање библиотечке делатности, нити га реално обавља. Број библиотечких радника у институтима регулисан је Правилником о националним стандардима за обављање библиотечко-информационе делатности (Министарство културе и информисања републике Србије. „Правилник о националним стандардима за обављање библиотечко-информационе делатности", Сл. іласник РС бр. 39 (2013), члан 9. став 5, http://www.nb.rs/view_file.php?file_id=3372 (преузето 10. 10. 2016)), али се његове одредбе у пракси не примењују. Због неспровођења релевантних закона и подзаконских аката, библиотеке у научноистраживачким организацијама и библиотекари запослени у њима налазе се у врло неповољном положају.

${ }^{6}$ E-CRIS (Electronic Current Research Information Systems) је веб-апликација коју је Институт информацијских знаности у Марибору (IZUM) бесплатно понудио корисницима COBISS платформе, како би се, у оквиру националних библиотечко-информационих система у мрежи COBISS.Net могла успоставити евиденција истраживача и установа, неопходна за вођење библиографија научних радника.
} 


\section{Библиографски сервиси и базе података доступни у Србији}

\section{(1) Библиоїрафије исйраживача зайослених на Универзииетеиу}

Систематично библиографско праћење научноистраживачког рада у Србији постојало је дуги низ година. Од 1963. па све до 1985. године Универзитетска библиотека „Светозар Марковић" у Београду, која је уједно и матична библиотека за научноистраживачке организације, започела је рад на праћењу и изради библиографије научних радова.

„На иницијативу Секретаријата Универзитета у Београду, 1964. године, изашла је из штам-

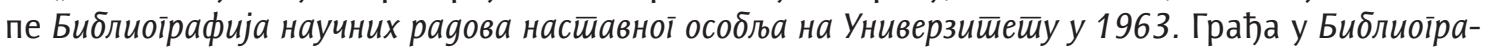
фији састављена је на основу упитника који је наставно особље на факултетима попуњавало за радове штампане у периоду 1. јануар - 31. децембар 1963. године. Обухваћени су радови са 18 факултета Универзитета у Београду, као и Високе школе за физичко васпитање и три факултета која су се развијала под окриљем Београдског универзитета (Правно-економски факултет у Нишу, Правно-економски факултет у Приштини и Економски факултет у Титограду)". ${ }^{7}$

Од 1964. до 1985. године Универзитетска библиотека „Светозар Марковић” наставаља да прати научноистраживачки рад на Универзитету кроз публикацију Пойис раgова насйавника и

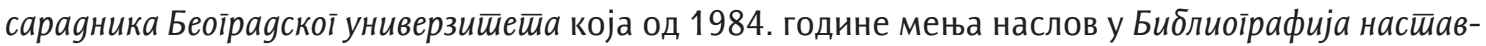

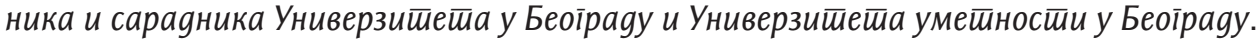

Грађа за ову библиографију у почетку је била груписана у оквиру факултета и распоређена по сродности на области хуманистичких, друштвених, природних и примењених наука, да би у последњем штампаном облику, 1985. године, била груписана абецедно по факултетима и обухватала научне и стручне радове са 24 факултета и седам института Београдског универзитета, као и свих факултета Универзитета уметности у Београду. Подаци су прикупљани како праћењем домаћих и страних часописа и пописаног обавезног примерка у Народној библиотеци Србије, тако и праћењем публикованих радова у Индексу цитираности за природне науке (Science Citation Index).

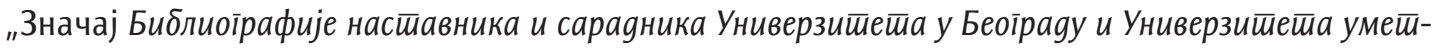
ности у Беоїраgу огледао се не само у томе што се ова публикација користила у свим научноистраживачким институцијама у земљи, него и што је путем међубиблиотечке позајмице и размене, коју је Универзитетска библиотека имала са око 150 библиотека и научноистраживачких институција у свету, доприносила афирмацији научноистраживачког рада Универзитета у иностранству".

Универзитетска библиотека „Светозар Марковић” је од 1945. године, као депозитна библиотека, примала дисертације са територије целе бивше Југославије. Како би се информације о овим дисертацијама што боље презентовале научној јавности, ова библиотека је у периоду од

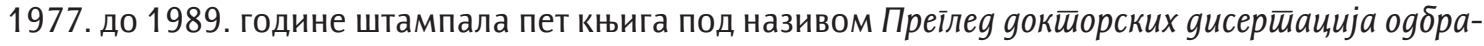
юених у Србији.

И поједини факултети Универзитета у Београду имају релативно дугу традицију објављивања библиографија својих наставника и сарадника. Тако су библиографије наставника и сарадника Филолошког факултета Универзитета у Београду објављене у две свеске Анала филолошкої факулиешеа, бр. 13 (1979) и бр. 17 (1986). Свеска 13 укључује радове наставника и сарадника објављене до краја 1975, а свеска 17 до краја 1984. године. Обе библиографије састоје се од појединачних персоналних библиографија сложених по азбучном редоследу презимена аутора, а у седамнаестој свесци опремљене су и биографијама наставника и сарадника. У ванредној књизи Анала из 2012. године сакупљене су и обједињене персоналне

\footnotetext{
7 Миле Стијеповић и др., „Од Пописа радова наставника и сарадника универзитета у Београду до библиографије истраживача Србије", у Сусрешии библиоїрафа у сйомен на gр Георіија Михаиловића, одговорни уредник Јелена Ђорђевић (Инђија: Народна библиотека „Др Ђорђе Натошевић", 2016), 225-232.$$
8 \text { Исто. }
$$ 
библиографије наставника и сарадника, као и библиотекара и чланова ненаставног особља за период од 1984. до почетка 2010. године. ${ }^{9}$ Овај факултет је, такође, започео и процес дигитализације културне баштине прво сопствених издања, која су окосница научне мисли у областима изучавања 34 језика и њима припадајућих књижевности и култура, као и у областима библиотекарства, информатике, архивистике и музеологије. ${ }^{10}$

\section{(2) Јуїословенски библиоїрафски инсииитуити (ЈУБНН)}

С обзиром на то да у некадашњој ФНРЈ, односно СФР), није дошло до оснивања централне државне библиотеке, а да је ипак морала да постоји институција која обавља функције које нису легитимно и у име целе земље могле да обављају поједине националне (републичке) библиотеке, основан је Југословенски библиографско-информацијски институт - ЈУБИН (1949. године, прво као Библиографски институт ФНРЈ, а касније као ЈУБИН). Настао је из Библиографског института Србије, основаног претходне године. Поједине функције непостојеће централне библиотеке Југославије ЈУБИН је успешно обављао чак и после распада СФР), али тада само за Савезну Републику Југославију. ${ }^{11}$

ЈУБИН је израђивао текућу библиографију Србије, која се састојала од серијских публикација:

- Библиоірафија луїославије која је обухватала следеће области: Књиге, брошуре и музикалије; Чланци и прилози у серијским публикацијама (Серија А - друштвене науке; Серија Б - природне и примењене науке; Серија Ц-филологија, уметност, књижевност и спорт). Серије А, Б и Ц излазиле се тромесечно, са регистром.

- Библиоірафија Јуїословенских серијских иуубликација, која је излазила једном годишње, са посебним кумулативним регистром. ${ }^{12}$

Иако својим форматом Библиоірафија Јуі̄ославије није била сасвим прилагођена потребама израде библиографија научних радника, она је представљала незаобилазан извор информација.

Формирање Југословенског библиографског института било је један од највећих националних пројеката у који су биле укључене библиотеке са простора бивше Југославије. Овај Институт је крајем 2002. године транформисан и један део кадрова прешао је у Народну библиотеку Србије, настављајући рад у разним одељењима. У фебруару 2003. године извршена је конверзија каталога када је ЈУБИН свој каталог објединио са каталозима Народне библиотеке Србије, Библиотеке Матице српске и Универзитетске библиотеке „Светозар Марковић”. Тако је настао узајамни електронски каталог познат под именом Виришуелна библиошеека Србије - ВБС. ${ }^{13}$ јУБИН је имао солидну методологију за праћење и израду свих врста библиографија која се могла преузети и користити у неком новом, савременом медијуму, али, нажалост, до тога није дошло. Једна од негативних последица гашења ЈУБИН-а, која значајно утиче на видљивост научног рада у Србији, јесте застој у текућој и ретроспективној аналитичкој обради серијских публикација, као и занемарљив број одабраних и обрађених чланака и прилога у зборницима радова.

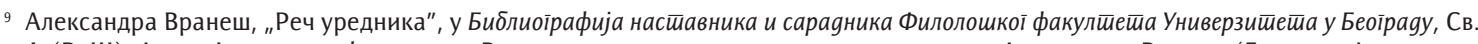
4, (Р-Ш), Анали Филолошкої факулешешаа, Ванредна књига, главни и одговорни уредник Александра Вранеш (Београд: Филолошки факултет Универзитета, 2012), 7-8.

${ }^{10}$ Филолошки факултет у Београду, „Дигитална библиотека”, Филолошки факултет, Универзитет у Београду, http://www.fil.bg.ac.rs/ lang/sr/biblioteke/digitalna-biblioteka/ (преузето 10. 3. 2017).

11 Послови од националног значаја које је ЈУБин обављао били су: израда текуће библиографије CPJ, издавање ISBN/ISSN броја, лиценца за превод и издавање УДК таблица, вођење и ретроспективна конверзија централног каталога страних публикација у библиотекама Југославије од 1919. године. Оформио је и Централни каталог страних књига и страних серијских публикација у библиотекама Југославије које су штампание после 1919. године и радио на његовој конверзији у електронски формат.

12 Поред наведених, ЈУБИН је од 1969. издавао Библиоірафију йревоgа у СФРЈ оgносно СР), од 1971. Библиоірафију званичних йубликаиија СФРЈ о оносно СРЈ, а од 1974. Библиоірафију ройо ийамйе и сиирийова.

${ }_{13}$ Видети Сретен Угричић, „ЈУБИН - статус и перспективе”, Народна библиотека Србије, https://www.nb.rs/view_file.php?file_id=620 (преузето 10. 10. 2016).
} 


\section{(3) Текућа библиоїрафија Србије}

Библиоірафија Србије, као текућа национална библиографија, ${ }^{14}$ региструје издавачку продукцију у Републици Србији. Као што је већ поменуто, у периоду од 1950. до 2002. године издавачка продукција Републике Србије регистрована је у Библиоїрафији луі̄ославије, коју је издавао ЈУБИН. Од 2003. године Библиоірафију Србије израђује и издаје Народна библиотека Србије према Закону о библиотечкој делатности. ${ }^{15}$ Од 2005. године Библиоірафија је доступна у онлајн издању. ${ }^{16}$

Библиоірафија Србије обухвата монографске и серијске публикације, чланке и прилоге у серијским публикацијама и некњижну грађу, у штампаном и електронском облику, издате у току текуће и претходне године. Издања из претходних година, закључно са 1990, заступљена су у годишњим кумулативним анексима.

Библиографски описи израђују се de visu на основу обавезног примерка Народне библиотеке Србије и Библиотеке Матице српске, као и на основу узајамног електронског каталога COBIB.SR а у складу са међународним стандардима ISBD, COMARC/B, Правилником и ирируиником за израgу абецеgних кашалоїа (I-II) Еве Вероне и другом стручном и приручном литературом (тезауруси, стручни речници, енциклопедије, лексикони, електронске базе података).

Библиоїрафија Србије - Моноїрафске йублкаиије излази тромесечно. Преводи и службене публикације региструју се и у посебним издањима на годишњем нивоу.

Библиоірафија Србије - Серијске йуликаиије излази годишње. Она делом представља наставак Библиоірафије Јуїославије - Серијске иубликаиије коју је Југословенски библиографско-информацијски институт објављивао од 1956. године.

Библиоірафија Србије. Члании и ирилози у серијским иуубликаиијама. Грађа за ову публикацију добија се селекцијом из обавезног примерка серијских публикација за области:

Серија А. Друштвене науке (наука уопште, филозофија, психологија, религија, демографија, статистика, социологија, политика, економија, право, социјална заштита, педагогија, етнологија, археологија, географија, историја);

Серија Б. Природне, примењене, медицинске и техничке науке (математика, физика, хемија, биологија, медицинске, техничке и примењене науке);

Серија Ц. Уметност, спорт, филологија, књижевност.

Када су у питању библиографије научних радника, од посебног је значаја чињеница да се уз поједина годишта Библиоїрафије Србије објављује и посебан Анекс који чине записи добије-

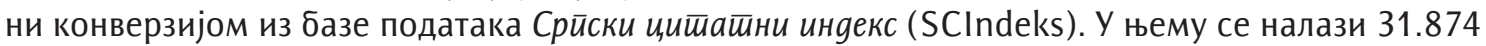
записа који су 2009. године импортовани из SCIndeksa а који нису били обухваћени текућом Библиоірафијом Србије - Члании и ирилози у серијским иуубликащијама. Записи су библиографски и садржински редиговани и додељени су им одговарајући УдК бројеви.

Нажалост, од 2002. до 2005. године постојао је застој у аналитичкој обради, што представља велики недостатак, имајући у виду да домаћи научни радници најчешће објављују у часописима и зборницима радова. Нако је било планирано да се, осим обраде зборника радова као монографских публикација, уради и њихова аналитичка обрада, због великог обима посла селективно

\footnotetext{
${ }^{14}$ Као изузетно важан извор свакако би требало споменути и Срйску библиоїрафију. Књиге 1868-1944. Рад на изради ове ретроспективне библиографије започет је пре више деценија. Близу сто педесет наших и светских, државних, јавних и приватних библиотека је прегледано да би се установило колико је и којих српских књига похрањено у њиховим фондовима. Срйска библиоїрафија. Књиге 1868-1944 објављена је у 20 томова, у њој је обрађено 100.854 библиографске јединице и она чини најцеловитији, најпотпунији и најпоузданији попис српских књига код нас. Ова обимна грађа српске библиографије књига је дигитализована и постављена на веб-страницу Народне библиотеке Србије, https://www.nb.rs/pages/article.php?id=1381 (преузето 25. 3. 2017). Њу је могуће претраживати преко кумулативне базе Ауторског и Предметног регистра чија је редакција још увек у току.

15 „Закон о библиотечкој делатности”, Службени іласник Рерублике Србије бр. 34 (1994), https://www.nb.rs/view_file.php?file_id=285 (преузето 25. 3. 2017).

${ }^{16}$ Народна библиотека Србије, Библиоїрафија Србије, https://www.nb.rs/pages/article.php?id=1384 (преузето 24. 3. 2017).
} 
су обрађени само поједини чланци. Захваљујући реорганизацији посла, од 2005. године учињен је значајан помак, ${ }^{17}$ али није било могуће постићи континуитет у обради свих чланака.

Аналитичка обрада чланака у часописима такође се ради селективно и то према одлукама и критеријумима којима се руководе каталогизатори у Одељењу серијских публикација. Први критеријум се односи на израду ЦИП-а за чланак који се пре објављивања уноси у базу података, а по објављивању ажурира и даље класификује. Други критеријум се односи на часописе у којима се чланци објављују. Они морају бити научни, имати што већу вредност и утицајност у домаћим и страним базама података, морају излазити редовно и бити лако доступни и у електронском облику. Поштовањем овог критеријума велики број обрађених чланака доступан је у пуном тексту. Трећи критеријум се односи на преузимање готових записа из других библиотека, најчешће из електронског каталога Универзитетске библиотеке, Библиотеке Матице српске и библиотеке Универзитета у Крагујевцу.

\section{(4) Елекйронски кайалози}

После распада Југославије било је неколико покушаја да се кроз пројекат План развоја библиошеике мреже Србије израде одвојени библиотечко-информациони системи који би обухватали територију Републике Србије. Такав један сервис је и БИСИС, пројекат који је финансирало Министарство за науку и технологију Републике Србије и Извршно веће Аутономне Покрајине Војводине. Овај библиотечки софтверски систем развијао се од 1992. године и до сада је доживео неколико дорађених савременијих верзија.

У току 2003. године на Универзитету у Новом Саду развијен је и софтверски систем Мрежна

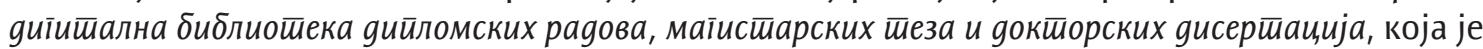
званично прикључена светској мрежи дигиталних библиотека (NDLTD). ${ }^{18}$ Од 2005. године траје реализација пројекта Библиошечка мрежа Војвоgине, који су подржали ресорни покрајински секретаријати Владе АП Војводине. ${ }^{19}$

У библиотекама научноистраживачких установа користе се различити програми за обраду библиотечке грађе и електронско пословање библиотеке. Осим COBISS-а и БИСИС-а, најчешће су у питању стара софтверска решења (Пергам, MMARC, Библио и други) која није могуће прилагодити савременим потребама, па ни искористити за израду библиографија истраживача.

\section{(5) Библиоірафске базе йоgайака}

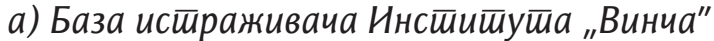

Ова база података настала је 2002. године у лабораторији за рачунарску технику, која је била претеча ИТ центра Института „Винча”. Тадашњи директор лабораторије имао је идеју да "оживи" науку и кроз овај пројекат је направљена првобитна база истраживача, а касније је прерађен и код (HTML+PHP+MySQL). ${ }^{20}$ Иако је била један од многобројних покушаја систематизовања научноистраживачког рада, бар у оквиру једне институције и, иако је она видљива и јавно доступна, треба напоменути да не задовољава основне техничке стандарде које једна библиографска база података мора да задовољи. Пре свега, у њу се не уносе библиографске

\footnotetext{
${ }^{17}$ Нпр. према испису из локалне базе НБС 2014. године урађено је 305 чланака, 2015. године 86 а 2016. године чак 1.408.

18 Душан Сурла и др. Дистирибуирани библиошечки информациони систем БНСИС (Нови Сад: Група за информационе технологије, 2004), http://www.bisis.rs/wp-content/uploads/2014/12/BISIS-monograph.pdf (преузето 20. 9. 2016).

${ }_{19}$ BISIS (Bibliotečko informacioni sistem), "Pregled razvoja BISIS-a”, http://www.bisis.rs/program/pregled-razvoja-bisisa/ (preuzeto 20. 9. 2016).

${ }^{20}$ База је јавно доступна на адреси http://www.vin.bg.ac.rs:446/._Информације о овој бази ауторка је добила од библиотекара Бранислава Ђурашевића, библиотекара у „Винчи”, који је задужен за пружање информација корисницима.
} 
јединице, него комплетни спискови радова научних радника. Саме референце у списковима нису обрађене у складу са библиографским стандардима, а стилови цитирања у документима се разликују. У цитираним референцама има много грешака. Подаци се не могу претраживати, а укупан број референци није могуће утврдити. Базу података одржава систем-администратор, а приступ имају регистровани истраживачи запослени у Институту који сами и добровољно уносе своје податке. Пошто унос и измене података нису обавезни, ова база није ажурна.

\section{б) Карйон научної раяника Војвоgине}

Карйон научної раяника представља базу података која садржи научне публикације свих регистрованих истраживача на територији Војводине. Настао је на захтев Покрајинског секретаријата за високо образовање и научноистраживачку делатност. Пријаву и регистрацију на вебсервис могу извршити сви истраживачи који су преко своје матичне установе поднели захтев Покрајинском секретаријату за додељивање АПВНТ броја. Увид у резултате истраживача из преко 50 институција, којих тренутно у бази има 5253, омогућен је у Преїлеgу реїистированих исйраживача, а остали подаци о истраживачима (основни подаци, избори у звања, биографије...) налазе се Каршиону. У делу Цитираност налазе се кумулативни резултати цитираности истраживача (укупан број цитата и аутоцитата) преузети од рефералног центра Библиотеке Матице српске. У делу Бодовање резултата по пољима налази се упоредни преглед бодовања по научним областима. Уз сваки М-резултат истраживача постоји и поље резултата на основу кога се резултат бодује.

Иако је база прегледна и садржи све неопходне информације, њен недостатак је начин разврставања резултата који је заснован на критеријумима и бодовној листи из Правилника о поступку, начину вредновања и квантитативном исказивању научноистраживачких резултата истраживача. Ови критеријуми су релевантни само за истраживаче из Србије и нису употребљиви у међународном контексту. Иако постоји могућност извоза и проширивања базе у тражене формате, она није пројектована према библиографским стандардима које би требало користити приликом реферисања радова домаћих научних радника. ${ }^{21}$

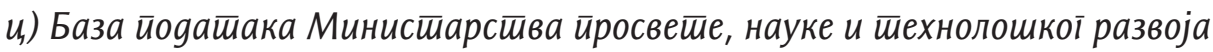

Већ дуги низ година научне институције које финансира ово Министарство дужне су да на крају сваке календарске године и на крају пројектних циклуса подносе извештаје о научним достигнућима истраживача који раде у Републици Србији. У самом Министарству никада није постојао јединствен програм за унос података, нити је направљена свеобухватна база истраживача Србије која би била јавно доступна и потпуно транспарентна. На крају сваког истраживачког циклуса Министарство тражи да се, најчешће у различите електронске базе података, уносе библиографске референце са свим неопоходним подацима (укључујући DOI, COBISS-ID, ISBN, ISSN). База података није урађена у складу са библиографским стандардима, због чега није омогућено преузимање података из других система. Унос података обавља се искључиво ручно, па су тачност и интегритет података дискутабилни. После завршетка уноса, који прате различити организациони и технички проблеми, извештаји су „закључани”, нису видљиви на веб-страници Министарства, нити се подаци који су већ једном унети у базу могу опет исправљати и допуњавати. Није познато да ли су базе резултата текућег и претходних пројектних циклуса обједињене у јединствен систем. ${ }^{22}$

\footnotetext{
${ }^{21}$ Univerzitet u Novom Sadu i Pokrajinski sekretarijat za nauku i tehnološki razvoj, "Karton naučnog radnika”, Centar za računarstvo, FTN, http://knr.uns.ac.rs/news.xhtml (preuzeto 27. 3.2017).

22 Закључак ауторке настао из личног увида у базе података у којима је више пута радила. Руководиоцима пројеката, администраторима и корисницима, осим општих упутстава, не доставља се никаква техничка документација. Није познато која и каква техничка платформа се користи, нити према којим стандардима се базе креирају.
} 


\section{(6) Диіийални рейозит̄оријуми}

Успостављање институционалних дигиталних репозиторијума још је један од начина који библиографске изворе чини доступним и видљивим. Као базе података у које се могу депоновати различите врсте докумената у различитм форматима (текстуални, графички, видео, аудио итд), дигитални репозиторијуми публикација представљају одличну инфраструктуру за израду библиографија, а њихова употребљивост, осим од техничких карактеристика, зависи и од садржаја који се уносе, квалитета метаподатака којима се описују различити објекти и нарочито од редовности похрањивања. Дигитални репозиторијуми омогућавају преузимање метаподатака из других система и пренос у друге системе који почивају на истом стандарду (xml, Dublin Core), а посредством протокола ОАI-PMH. ${ }^{23}$ Данас постоји широк спектар софтверских плаформи отвореног кода за дигиталне репозиторијуме (Dspace, E-Prints, Invenio итд).

Иако су дигитални репозиторијуми подесни и једноставни за рад и у великој мери покривају како потребе израде библиографија, тако и потребе дисеминације публикација научних радника, у Србији их данас нема много и нису сигуран, поуздан и трајан сервис. С обзиром на то да њихово одржавање зависи од институција у којима се налазе, а оне ретко имају одговарајућу и непоходну техничку подршку, проблем би се дугорочно могао решити успостављањем мреже институционалних репозиторијума и једиственог националног агрегатора који би прикупљао податке у централну базу података. Уз увођење обавезе депоновања свих научних резултата, такав систем би представљао одличну основу за израду библиографија научних радника и институција.

У даљем тексту наведени су неки од тренутно активних репозиторијума у Србији. ${ }^{24}$

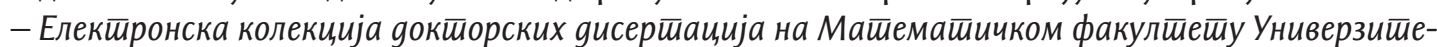
$\bar{u} а$ у Беоїраgу један је од првих корака успостављања репозиторијума. ${ }^{25}$

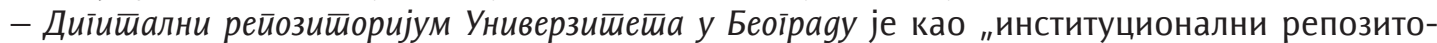
ријум намењен систематском управљању збирком електронских докторских дисертација, а потенцијално и збиркама осталих радова Универзитета. У том репозиторијуму могу да се архивирају и презентују радови наставника и сарадника Универзитета", ${ }^{26}$ али се он углавном не користи у те сврхе. Од 2012. године докторске дисертације трајно се чувају у дигиталном репозиторијуму Е-тезе који представља интегрални део Дигиталног репозиторијума PHAIDRA (Permanent Hosting, Archiving and Indexing of Digital Resources and Assets). ${ }^{27}$ У овом репозиторијуму чувају се докторске дисертације Универзитета у Београду, Крагујевцу и Нишу и оне су трајно архивиране, класификоване, описане метаподацима и доступне научној јавности. Репозиторијум садржи и један број старијих дисертација које су одбрањене на Универзитету у Београду у периоду од 1905. до 1941. године.

\footnotetext{
${ }^{23}$ Више о овоме видети у Jackson S. Amy et al., "Dublin Core Metadata Harvested Through OAI-PMH", Journal of Library Metadata 8, no. 1 (9 April 2008): 5-21. doi:10.1300/J517v08n01_02. http://www.tandfonline.com/doi/pdf/10.1300/J517v08n01_02?needAccess=true (preuzeto 25. 3. 2017).

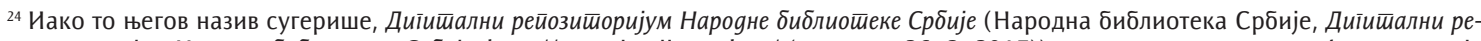
йозитиоријум Нароgне библиоетеке Србије, http://repozitorijum.nb.rs/ (преузето 26. 3. 2017)) ни концептуално, ни софтверски није репозиторијум у правом смислу те речи. То је архива PDF докумената у коју се, у складу са договором са Министарством просвете, науке и технолошког развоја, похрањују и трајно чувају сва издања домаћих научних часописа који се објављују у Републици Србији. Уз помоћ ове базе података могуће је пратити редовност излажења наших научних часописа (на основу датума депоновања), иако комплетни текстови из њих нису јавно доступни.

${ }_{25}$ Matematički fakultet Univerziteta u Beogradu, „E-biblioteka”, Nacionalni centar za digitalizaciju, http://elibrary.matf.bg.ac.rs/ (preuzeto 22. 10. 2016).

${ }^{26}$ Гордана Мазић и др., „Библиографије и репозиторијуми: непомирљиви антагонисти или протагонисти исте идеје”, у Срйска наиионална библиоїрафија: зборник раgова, главни и одговорни уредник Светлана Јанчић (Београд: Народна библиотека Србије, 2014), 147.

27 Универзитетска библиотека „Светозар Марковић”, Е-шезе Универзишешеа у Беоїраgy, http://eteze.bg.ac.rs/ (преузето 25. 3. 2017).
} 
- У периоду између 2013. и 2015. године још су три институције - Институт техничких наука САНУ, ${ }^{28}$ Институт за филозофију и друштвену теорију ${ }^{29}$ и Институт економских наука ${ }^{30}$ из Београда успоставиле дигиталне репозиторијуме у које су почеле да уносе метаподатке и депонују радове сарадника института. Основу прва два репозиторијума чини софтвер отвореног кода OPUS4, који је израдио Центар за информациону технику „Konrad Cuze” из Берлина. Податке из ових репозиторијума преузимају Google Scholar, WorldCat, BASE, CORE и други агрегатори, тако да се информације о радовима истраживача презентују и светској научној заједници. Нажалост, поменути репозиторијуми нису део неког већег и дугорочнијег пројекта, него се одржавају искључиво захваљујући ентузијазму библиотекара. Репозиторијум Института економских наука почива на софтвеpy E-Prints, израђеном у Школи за електронику и рачунарство Универзитета у Саутхемптону.

- У току 2016. године Институт за биолошка истраживања „Синиша Станковић” и Рачунарски центар Универзитета у Београду успешно су реализивали пројекат развоја платформе институционалног репозиторијума под називом РАДаР - Репозиторијум дигиталних архивираних радова. Он је кључно место за прикупљање, чување и дисеминацију резултата истраживача Института. Ово је први институционални репозиторијум у Србији који испуњава захтеве Европске комисије о обавезном отвореном приступу радовима насталим у оквиру пројеката из циклуса Хоризонт 2020, као и обавезу које је надлежно Министарство дало у позиву за финансирање пројеката у 2016. да истраживачи своје радове у пуном тексту депонују у репозиторијуме. У потпуности је усклађен са захтевима конзорцијума OpenAIRE. У репозиторијуму се у овом тренутку налази око 2500 записа. Развијен је на програмском пакету за репозиторијуме отвореног кода Dspace, који, између осталог, задовољава стандарде интероперабилности уобичајене за институционалне репозиторијуме. Његово уређивање, односно унос података и брига о ауторским правима је обавеза библиотеке Института. ${ }^{31}$

У Србији је успостављање институционалних репозиторијума још увек у зачетку, али свакако треба истаћи напредак у њиховом одржавању и развоју, нарочито у Институту економских наука и Институту за биолошка истраживања који имају потпуну подршку својих управа.

- Од 2015. године покренут је и портал НаРдУС (Национални Репозиторијум Дисертација у Србији) који је израђен у складу са смерницама пројекта Европске уније за истраживање и иновације (Хоризонт 2020) и којим се подстиче учешће наших високошколских институција у архивирању докторских дисертација у европски репозиторијум докторских дисертација. ${ }^{32}$

\section{(7) Национални елекйронски сервиси}

\section{а) Вирӣуелна библиотееке Србије}

Највећим националним библиотечким пројектом - Виртуелном библиотеком Србије у нашој земљи успостављена је основа за стварање јединственог библиотечко-информационог система и постигнута је много већа видљивост библиографских података кроз различите начине претраживања и кроз коришћење великог броја електронских библиотечких каталога, сервиса и других база података. У овај сервис се, од укупно 2553 библиотеке у Србији, ${ }^{33}$ до сада укључило

\footnotetext{
${ }^{28}$ Institut tehničkih nauka Srpske akademije nauka i umetnosti, "Digital repository of the Institute of Technical Sciences of SASA", ITN, http://www.itn.sanu.ac.rs/biblioteka-opus4.html (preuzeto 22. 9. 2016).

${ }^{29}$ Institut za filozofiju i društvenu teoriju, Univerzitet u Beogradu, „Digitalni repozitorijum Instituta za filozofiju i društvenu teoriju”, IFDT, http://www.instifdt.bg.ac.rs/repoziturijum-radova/ (preuzeto 22. 9. 2016).

${ }^{30}$ Institut ekonomskih nauka, „Ebooks repository”, IEN, http://ebooks.ien.bg.ac.rs/_(preuzeto 22. 9. 2016).

${ }^{31}$ Univerzitet u Beogradu, Institut za biološka istraživanja "Siniša Stanković", RADaR, http://www.ibiss.bg.ac.rs/?lan=0\&menu=472 (preuzeto 27. 3. 2017).

32 Univerzitet u Beogradu, "NaRDUS - Nacionalni repozitorijum disertacija u Srbiji”, http://nardus.mpn.gov.rs/ (preuzeto 22. 9. 2016).

${ }_{33}$ Републички завод за статистику, Сшайисиички каленяар Рейублике Србије (Београд: Републички завод за статистику, 2016), 98, http://webrzs.stat.gov.rs/WebSite/repository/documents/00/02/07/26/Statisticki_kalendar_2016.pdf (преузето 5. 8. 2016).
} 
више од 180 библиотека и стално се укључују нове. Ако узмемо у обзир да се међу њима налазе и три најзначајније библиотеке Србије (НБС, БМС, УБ „Светозар Марковић”) које имају и највеће фондове ${ }^{34}$ и да тренутно узајамни електронски каталог садржи преко 8.000.000 библиографских записа, ${ }^{35}$ онда се досадашњи резултати овог пројекта могу сматрати задовољавајућим.

Софтверску основу ВБС чини COBIB.SR, који је као узајамна библиографско-каталошка база података део COBISS.net мреже и кроз који се међусобно повезују аутономни, односно национални библиографски системи из неколико европских држава. Ова база података садржи библиографске записе о књижној (монографске и серијске публикације) и некњижној грађи (CD и DVD издања). За размену података у систему COBISS користе се формат COMARC/B за библиографске податке и формат COMARC/A за нормативне податке, који су засновани на формату UNIMARC. ${ }^{36}$

\section{ס) E-CRISS.SR}

E-CRISS.SR је специјализована веб-апликација коју је Институт информацијских знаности у Марибору бесплатно понудио корисницима COBISS апликација како би се, у оквиру националних библиотечко-информационих система у мрежи COBISS.net, могла успоставити евиденција истраживача и установа неопходна за вођење библиографија научних радника и за евалуацију њиховог рада. У последње време ова база се допуњује и описима тока и резултата различитих истраживања кроз успостављање веза са другим библиографским и мултимедијалним базама које су међусобно повезане. Већина података је на српском и енглеском језику.

Kрајем 2005. године урађена је прва конверзија података о истраживачима из Србије у E-CRISS.SR (наставници и сарадници са 16 факултета Београдског универзитета), ${ }^{37}$ тако да се као почетак рада веб-апликације која представља информациони систем о истраживачкој делатности у Србији може узети 2006. година. E-CRISS.SR је апликација усаглашена са препорукама CERIF-a (Common European Research Information Format) који прописује структуру података о истраживачким пројектима, а обухвата и препоруке за истраживачке организације, одељења и истраживаче. У оквиру информационог система E-CRISS.SR налазе се базе података о истраживачким организацијама, одељењима организација, истраживачима и пројектима које су међусобно повезане.

E-CRISS.SR повезан је са информационим системом COBISS.SR, односно његовом библиографском базом и, захваљујући томе, корисницима овог система омогућен је непосредан увид у библиографије научних радника. Дакле, битно је напоменути да 2006. година представља почетак израде Библиографије истраживача Србије, односно прелазак са библиографије Универзитета у Београду и Универзитета уметности у Београду на библиографију целе истраживачке заједнице Србије.

Персоналне библиографије могу да се испишу директно из система E-CRISS.SR или преко опције Библиографије и E-CRISS.SR у COBISS.SR систему. Приликом исписа, може се дефинисати период на који се библиографија односи, а могуће је одабрати и један од пет формата библиографске јединице (ISO, IEEE, ISBD, ISBD у збијеном облику и ISO са исписом свих

\footnotetext{
${ }^{34}$ Народна библиотека Србије, „Подаци о српским библиотекама - COLIB.SR”, Виртуелна библиотека Cpбије, http://www.vbs.rs/scripts/ cobiss?ukaz=BASP\&bno=507\&id=1143502260976025 (преузето 26. 10. 2016). Укупан број ових библиотека чине: 80 народних библиотека, 73 високошколске и 30 специјалних библиотека. Школске библиотеке које су иначе најбројније (1523) нису укључене у овај систем.

${ }_{35}^{5}$ Народна библиотека Србије, „Пуноправни чланови система COBISS.SR и њихово учешће у систему узајамне каталогизације: библиографске базе података и подаци о фонду", Виртуелна библиотека Србије, http://vbshome.vbs.rs/sr/o_cobissu/dokumenti/ STAT_PRIRAST_2015_SR_1.pdf (преузето 11. 8. 2016).

${ }^{36}$ За међународну размену библиографских података користи се формат MARC 21. Могуће су конверзије записа из формата COMARC у MARC 21 и обратно. Записи се могу експортовати у структури ISO 2709 (MARC 21, COMARC) или XML (Dublin Core, MODS, MARC 21, COMARC).

${ }^{37}$ У разговору са колегом Милетом Стијеповићем из УБ „Светозар Марковић”, који ради на одржавању и развоју ове базе, ауторка рада добила је информације да је 2005. године урађена анкета на Београдском универзитету и да је један део факултета доставио тражене податке у табелама са датотекама у Word-овим фајловима које су конвертоване у E-CRISS.
} 
аутора). Библиографске јединице се могу сортирати на више начина, а испис може бити у HTML или XML формату. Могуће је изабрати и језик, односно писмо библиографије. ${ }^{38}$

У бази је тренутно регистровано 10.942 истраживача, 286 организација, 830 истраживачких одељења и 777 пројеката. ${ }^{39}$ Нажалост, потпуни библиографски подаци доступни су само за оне истраживаче чије су матичне институције део система COBISS.SR. Највећи број библиотека научноистраживачких института није део тог система, па веома важан део продукције домаћих научника није покривен у бази података E-CRISS.SR.

Свакако је значајно истаћи да се ова база изузетно развила у Словенији и да су у словеначкој бази SICRIS, уз основна претраживања, развијена и нова, као што су библиографски показатељи успешности, вредновање групе истраживача, најуспешнији истраживачи, најугледније публикације и мониторинг који прати научни рад словеначких аутора и који је повезан са Wos-om i Scopus-ом. ${ }^{40}$

\section{u.) Hamu y WoS-y}

Hamu y WoS-y је база података у оквиру веб-странице националног библиотечког конзорцијума КоБСОН. Она даје увид у радове домаћих аутора који су индексирани у цитатној бази података Web of Science. Министарство просвете, науке и технолошког развоја ју је оценило као референтну у вредновању резултата научног рада. Ова база података није рађена са идејом да буде свеобухватна библиографска база, већ средство које ће домаћим научницима омогућити бржи приступ до информација о међународној видљивости њихових научних резултата. Библиографски подаци о радовима истраживача редовно и аутоматски се ажурирају преузимањем података из Web of Science. Уз помоћ одговарајуће API апликације доступни су подаци о цитираности појединачних радова у индексним базама података Web of Science и Scopus. ${ }^{41}$

\section{g) Срйски иитиатини индекс}

Још једна релевантна и корисна база података која се делимично може користити и као библиографска база јесте Срйски иитиатини индекс (СЦИндекс) који одржава Центар за евалуацију у образовању и науци. ${ }^{42}$ У овом сервису реферишу се домаћи часописи који су категорисани као периодичне публикације научног карактера. Индексирају се систематски „од корица до корица", па се у оквиру метаподатака, осим наслова и сажетака радова, могу наћи и све цитиране референце. Метаподаци из СЦИндекса доступни су у сервису Google Scholar. До 2015. године Српски цитатни индекс је обухватао преко 400 часописа, а престанком јавног финансирања дошло је до промене пословног модела, па су услуге индексирања доступне само часописима који су на то претплаћени. Због тога је број часописа који се индексирају у СЦИндексу знатно мањи - 228. Вредност ове базе података је у томе што је велики број чланака доступан и у виду пуног текста. ${ }^{43}$ Од почетка 2017. године метаподатке из СЦИндекса преузима и европски агрегатор OpenAire, а профили аутора повезани су са ORCID профилима (за оне ауторе који их имају).

\footnotetext{
${ }^{38}$ Миле Стијеповић и др., Нав. дело, 225-232.

${ }^{39}$ Народна библиотека Србије, E-CRISS.SR, http://e-cris.sr.cobiss.net/public/jqm/cris.aspx?lang=scr\&opdescr=home\&opt=1 (преузето 26. 3. 2017).

${ }^{40} \mathrm{COBISS} /$ SciMet za spremljanje znanstvene produkcije slovenskih avtorjev, http://scimet.izum.si/ (preuzeto 26. 3. 2017).

${ }^{41}$ Биљана Косановић и Татјана Тимотијевић, „Научни радови истраживача из Србије у Web of Science”, у Срйска национална библиоірафија: зборник раgова, главни и одговорни уредник Светлана Јанчић (Београд: Народна библиотека Србије, 2014), 169-176.

${ }^{42}$ Ова база покрива само део домаћих часописа и у њој није могуће груписати сва имена аутора у један профил.

${ }^{43}$ Centar za evaluaciju nauke "SCIndeks - Srpski citatni indeks”, http://scindeks.ceon.rs/Default.aspx (preuzeto 26. 10. 2016). У време израде овог рада у овом сервису било је 1.078 .512 референци из 73.835 чланака, од којих 32.928 у виду пуног текста, који су објављени у домаћим часописима од 2000. надаље, односно, у хуманистичким дисциплинама од 1996, а у друштвеним наукама, од 1991. године.
} 
Наши у WoS-y и Српски цитани индекс су базе података које су значајне због тога што промовишу наше истраживаче и прате њихову цитираност, али оне ипак не дају потпуни библиографски преглед и увид у научну продукцију не само појединих, него ни у укупан број свих научних радова у Србији. Због тога што највећим делом прате и реферишу само чланке у одабраним научним часописима и не прате друге врсте библиографске грађе, као што су монографије и прилози у зборницима радова, ова два сервиса не могу се третирати као потпуни библиографски извори, али свакако могу бити значајна допуна за израду целовитих библиографија истраживача, па су због тога и наведени у овом прегледу.

\section{(8) Међународни елекйронски сервиси - ORCID (Open Researcher and Contributor ID)}

$\mathrm{ORCID}^{44}$ је организација која одржава отворену и независну базу података о истраживачима и њиховом научном раду у целом свету. На основу унетих личних и професионалних података генерише се алфанумерички коิд који представља јединствену ознаку за идентификацију истраживача. На тај начин се решава проблем препознатљивости аутора и трајно се дефинише његов идентификатор у научном свету, изражен преко ИД ознаке.

Ова база је интероперабилна, што значи да се у њу или из ње могу увозити и извозити метаподаци из других система. Повезан је са WoS-ом и Scopus-oм - ове две базе података испоручују метаподатке ORCID-y. ${ }^{45}$ С друге стране, Web of Science и Scopus користе јавно доступне метаподатке из ORCID-a како би поправили квалитет података о ауторима (WoS), односно квалитет ауторских профила (Scopus) унутар својих система. Захваљујући овој интеграцији обе базе података могу се претраживати по ORCID идентификатору аутора. Уколико се радови не могу преузети из било које јавно доступне базе података, метаподаци се у ORCID могу унети и ручно, што значи да је могуће формирати комплетну персоналну библиографију.

\section{Закључак}

Анализа набројаних начина прикупљања грађе за израду библиографија научних радника у Србији указује на многе недостатке који су се појавили у националној ретроспективној и текућој библиографији. Тако је један релативно мали број института објављивао библиографије својих издања у целини ${ }^{46}$ или као део неког зборника радова поводом значајних годишњица, што свакако треба да буде један од параметара за укључивање ових радова (посебно у аналитичкој обради) у националну библиографију научноистраживачког рада.

${ }^{44}$ ORCID (Open Researcher and Contributor ID), https://orcid.org/ (preuzeto 26. 3. 2017).

${ }^{45}$ Више о ORCID-у видети у Laurel L. Haak et al., "ORCID: A System to Uniquely Identify Researchers", Learned Publishing 25, no. 4 (1 October 2012): 259-264. doi:10.1087/20120404 http://onlinelibrary.wiley.com/doi/10.1087/20120404/epdf (preuzeto 25. 2. 2017)

${ }^{46}$ Према резултатима исписа из COBISS-а овај број је, у односу на укупан број научноистраживачких организација у Србији (63), заиста мали. Само је 14 института објавило библиографије својих издања.

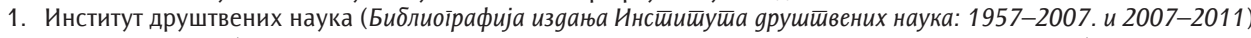

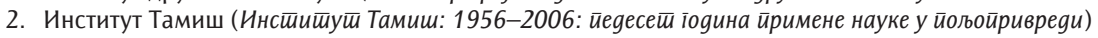

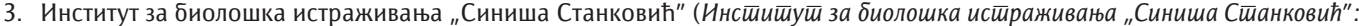
1987-1992)

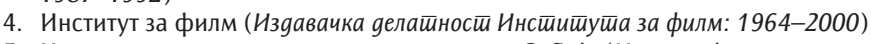

5. Институт за истраживања у пољопривреди Србије (Извештај о науиноистираживачком раяу за 2002. іолину)

6. Институт за књижевност и уметност (Библиоірафија издања: (1962-1992))

7. Институт за кукуруз „Земун Поље” (Библиоїрафија раяова и ЗП gосиииїнћа)

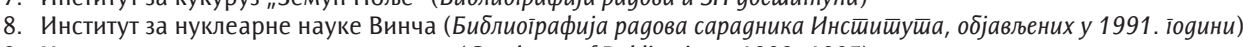

9. Институт за педагошка истраживања (Catalogue of Publications: 1990-1995)

10. Институт за савремену историју (Библиоїрафија Инсииишуша за савремену истиорију: 1995-2000. - објављена као сепарат у: Нсйорија 20. века бр. 2 (2001))

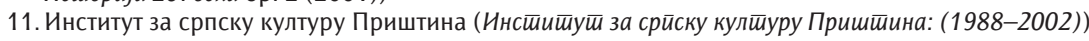

12. Institut za transfuziju krvi Srbije (Bibliografija: radovi stručnjaka Instituta za transfuziju krvi Srbije: od 1944. do 2004. godine)

13. Institut za voćarstvo (60 godina Centra za voćarstvo i vinogradarstvo i 70 godina Instituta za voćarstvo)

14. Institut za zaštitu bilja i životnu sredinu (Institut za zaštitu bilja i životnu sredinu: 1945-1995). 
Много чешћи је случај да су институти објављивали персоналне или тематске библиографије и библиографије научних и стручних часописа чији су били издавачи. Детаљније информације о издавачкој делатности института и истраживача углавном су биле праћене преко различитих билтена за интерну употребу који нису библиографски регистровани и нису адекватно смештени у библиотечке фондове и који су вероватно спорадично и сачувани. У скорије време, пројектни извештаји о радовима истраживача периодично су, у различитим онлајн верзијама, достављани надлежним министарствима. Нажалост, те верзије су рађене у лоше осмишљеним програмима који нису имали дуготрајан континуитет у архивирању нити стандардизована библиографска правила приликом уноса података. Чињеница је да подаци из тих извештаја нису јавно доступни и да су такве информације о радовима и научним достигнућима истраживача за ширу научну јавност потпуно невидљиве.

Иако у нашој земљи постоји више различитих библиографских база и сервиса, они нису обједињени, па су тако и библиографије радова истраживача присутне на различитим местима која нису међусобно повезана (пре свега у смислу јединствених стандарда на којима почивају) и из којих се не могу добити сви разултати научног рада одређеног аутора.

Да би се овај проблем превазишао и да би се сви доступни извори узајамно користили, повезали и уједначили, оптимално решење у овом тренутку је приступање библиотека научноистраживачких организација COBISS-y, односно ECRIS-y. На тај начин би се избегло расипање ресурса и дуплирање података, а научној заједници и ресорном министарству би се омогућило да кроз само једну централну базу података имају увид у националну научну продукцију.

Друго, лако изводљиво и могуће решење јесте да сви истраживачи креирају профиле у ORCID-y, где би библиографски подаци, који би се редовно ажурирали, били јавно видљиви. Интерактивне ORCID ознаке лако се интегришу у дигиталне репозиторијуме, платформе за издавање часописа и агрегаторе, па би се креирањем ORCID профила истраживача омогућила не само већа видљивист библиографија истраживача, него би се олакшала њихова идентификација у поменутим базама података.

Треће решење подразумевало би успостављање мреже институционалних дигиталних репозиторијума и централног националног агрегатора, који би, поред података из дигиталних репозиторијума, могао да преузима метаподатке и из система COBISS, будући да се записи из тог система могу експортовати у компатибилном формату. ${ }^{47}$ Осим што би олакшало израду библиографија научних радника, ово решење би омогућило отворени приступ великом броју научних публикација. Библиографима би био омогућен приступ пуном тексту свих публикациja, што би знатно побољшало квалитет библиографија.

\section{Литература и извори:}

1. Amy, Jackson et al. "Dublin Core Metadata Harvested Through OAI-PMH". Journal of Library Metadata 8 , no. 1 (9 April 2008): 5-21. doi:10.1300//517v08n01_02 http://www.tandfonline.com/doi/pdf/10.1300/ J517v08n01_02?needAccess=true (preuzeto 25. 3. 2017).

2. BISIS (Bibliotečko informacioni sistem). „Pregled razvoja BISIS-a”. http://www.bisis.rs/program/ pregled-razvoja-bisisa/ (preuzeto 20. 9. 2016).

3. Vraneš, Aleksandra. „Reč urednika”. U Bibliografija nastavnika i saradnika Filološkog fakulteta Univerziteta u Beogradu, Sv. 4 (R-Š). Anali Filološkog fakulteta. Vanredna knjiga. Glavni i odgovorni urednik Aleksandra Vraneš. Beograd: Filološki fakultet Univerziteta, 2012.

4. DiVA - Academic Archive On-line. http://www.diva-portal.org/smash/aboutdiva.jsf?dswid=-4540, (preuzeto 20. 2. 2017).

\footnotetext{
47 Добар пример таквог агрегатора који покрива и каталоге и репозиторијуме је шведски портал DiVA - Academic Archive On-line, http://www.diva-portal.org/smash/aboutdiva.jsf?dswid=-4540, (preuzeto 20. 2. 2017).
} 
5. „Zakon o bibliotečkoj delatnosti”. Službeni glasnik Republike Srbije br. 34 (1994). https://www.nb.rs/ view_file.php?file_id=285 (preuzeto 25. 3. 2017).

6. Institut ekonomskih nauka. "Ebooks repository". IEN. http://ebooks.ien.bg.ac.rs/_(preuzeto 22. 9. 2016).

7. Institut "Vinča”. Baza istraživača Instituta "Vinča". http://www.vin.bg.ac.rs:446/ (preuzeto 5. 3. 2017).

8. Institut tehničkih nauka Srpske akademije nauka i umetnosti. "Digital repository of the Institute of Technical Sciences of SASA". ITN. http://www.itn.sanu.ac.rs/biblioteka-opus4.html (preuzeto 22. 9. 2016).

9. Institut za filozofiju i društvenu teoriju, Univerzitet u Beogradu. „Digitalni repozitorijum Instituta za filozofiju i društvenu teoriju". IFDT. http://www.instifdt.bg.ac.rs/repoziturijum-radova/ (preuzeto 22. 9. 2016).

10. Kosanović, Biljana i Tatjana Timotijević. „Naučni radovi istraživača iz Srbije u Web of Science”. U Srpska nacionalna bibliografija: zbornik radova. Glavni i odgovorni urednik Svetlana Jančić, 169-176. Beograd: Narodna biblioteka Srbije, 2014.

11. Mazić, Gordana, Dragana Stolić i Bogoljub Mazić. „Bibliografije i repozitorijumi: nepomirljivi antagonisti ili protagonisti iste ideje". U Srpska nacionalna bibliografija: zbornik radova. Glavni i odgovorni urednik Svetlana Jančić, 147 i 156. Beograd: Narodna biblioteka Srbije, 2014.

12. Matematički fakultet Univerziteta u Beogradu. „E-biblioteka”. Nacionalni centar za digitalizaciju. http://elibrary.matf.bg.ac.rs/ (preuzeto 22. 10. 2016).

13. Milenković-Vuković, Biljana i Milica Ševkušić. „Biblioteke naučnoistraživačkih instituta i ustanova: zakonodavni okvir i praksa". Čitalište 15, br. 33 (2016): 18-29.

14. Ministarstvo prosvete, nauke i tehnološkog razvoja republike Srbije. „Zakon o naučno-istraživačkoj delatnosti". Sl. glasnik RS br. 110 (2005), 50 (2006) - ispr., 18 (2010) i 112 (2015). http://www.mpn. gov.rs/wp-content/uploads/2015/09/Zakon-o-NID-iz-Paragrafa-sl-gl.-112-iz-2015-preciscen-tekst. pdf. (preuzeto 26. 10. 2016).

15. Ministarstvo prosvete, nauke i tehnološkog razvoja. „Spisak akreditovanih instituta". http://www.mpn. gov.rs/wp-content/uploads/2015/08/Akreditovani-instituti-sredjeno-cir-12-1.pdf (preuzeto 20. 10. 2016).

16. Ministarstvo kulture i informisanja republike Srbije. „Pravilnik o nacionalnim standardima za obavljanje bibliotečko-informacione delatnosti". Sl. glasnik RS br. 39 (2013). http://www.nb.rs/view_ file.php?file_id=3372. (preuzeto 10.10. 2016).

17. Narodna biblioteka Srbije. Bibliografija Srbije. Virtuelna biblioteka Srbije. https://www.nb.rs/pages/ article.php?id=1384 (preuzeto 24. 3. 2017).

18. Narodna biblioteka Srbije. Digitalni repozitorijum Narodne biblioteke Srbije. Virtuelna biblioteka Srbije. http://repozitorijum.nb.rs/ (preuzeto 26. 3. 2017).

19. Narodna biblioteka Srbije. E-CRISS.SR. http://e-cris.sr.cobiss.net/public/jqm/cris.aspx?lang=scr\&opde $\mathrm{scr}=$ home\&opt=1 (preuzeto 26. 3. 2017).

20. Narodna biblioteka Srbije. „Podaci o srpskim bibliotekama - COLIB.SR”. Virtuelna biblioteka Srbije. http://www.vbs.rs/scripts/cobiss?ukaz=BASP\&bno=507\&id=1143502260976025 (preuzeto 26. 10. 2016).

21. Narodna biblioteka Srbije. „Punopravni članovi sistema COBISS.SR i njihovo učešće u sistemu uzajamne katalogizacije: bibliografske baze podataka i podaci o fondu". Virtuelna biblioteka Srbije. http://vbshome.vbs.rs/sr/o_cobissu/dokumenti/STAT_PRIRAST_2015_SR_1.pdf (preuzeto 11. 8. 2016).

22. Narodna biblioteka Srbije. Srpska bibliografija. Knjige 1868-1944. https://www.nb.rs/pages/article. php?id=1381 (preuzeto 25. 3. 2017).

23. Nacionalni savet za naučni i tehnološki razvoj. Nauka u Srbiji 2010-2013. Beograd: Konferencija univerziteta Srbije - KONUS, 2014. http://rodos.edu.rs/wp-content/uploads/2014/12/Knjiga-Naukau-Srbiji-2010-2013.pdf (preuzeto 26. 10. 2016).

24. ORCID (Open Researcher and Contributor ID). https://orcid.org/ (preuzeto 26. 3. 2017).

25. Republika Srbija. Republički zavod za statistiku. Statistički godišnjak za 2016. godinu. http://webrzs.stat. gov.rs/WebSite/repository/documents/00/02/28/92/18_Nauka_i_kultura.pdf (preuzeto 10. 3. 2017).

26. Republički zavod za statistiku. Statistički kalendar Republike Srbije. Beograd: Republički zavod za statistiku, 2016. http://webrzs.stat.gov.rs/WebSite/repository/documents/00/02/07/26/Statisticki_ kalendar_2016.pdf (preuzeto 5. 8. 2016). 
27. Stijepović, Mile, Ljiljana Stanković i Branka Nogić. „Od Popisa radova nastavnika i saradnika univerziteta u Beogradu do bibliografije istraživača Srbije". U Susreti bibliografa u spomen na dr Georgija Mihailovića. Odgovorni urednik Jelena Đorđević, 225-232. Inđija: Narodna biblioteka „Dr Đorđe Natošević", 2016.

28. Surla, Dušan i dr. Distribuirani bibliotečki informacioni sistem BISIS. Novi Sad: Grupa za informacione tehnologije, 2004. http://www.bisis.rs/wp-content/uploads/2014/12/BISIS-monograph.pdf (preuzeto 20. 9. 2016).

29. Ugričić, Sreten. „JUBIN - status i perspektive”. Narodna biblioteka Srbije. https://www.nb.rs/view_file. php?file_id=620 (preuzeto 10.10. 2016).

30. Univerzitet u Beogradu. "NaRDUS - Nacionalni repozitorijum disertacija u Srbiji”. http://nardus.mpn. gov.rs/ (preuzeto 22. 9. 2016).

31. Univerzitet u Beogradu, Institut za biološka istraživanja "Siniša Stanković". RADaR. http://www.ibiss. bg.ac.rs/?lan=0\&menu=472 (preuzeto 27. 3. 2017).

32. Univerzitet u Novom Sadu i Pokrajinski sekretarijat za nauku i tehnološki razvoj. „Karton naučnog radnika". Centar za računarstvo, FTN. http://knr.uns.ac.rs/news.xhtml (preuzeto 18. 8. 2016).

33. Univerzitetska biblioteka "Svetozar Marković". E-teze Univerziteta u Beogradu. http://eteze.bg.ac.rs/ (preuzeto 25. 3. 2017).

34. Filološki fakultet u Beogradu. „Digitalna biblioteka”. Filološki fakultet, Univerzitet u Beogradu. http:// www.fil.bg.ac.rs/lang/sr/biblioteke/digitalna-biblioteka/ (preuzeto 10. 3. 2017).

35. Haak, Laurel L., Martin Fenner, Laura Paglione, Ed Pentz, and Howard Ratner. "ORCID: A System to Uniquely Identify Researchers". Learned Publishing 25, no. 4 (1 October 2012): 259-264. doi:10.1087/20120404 http://onlinelibrary.wiley.com, /doi/10.1087/20120404/epdf (preuzeto 25. 2. 2017).

36. Centar za evaluaciju nauke. „SCIndeks Srpski citatni indeks”. http://scindeks.ceon.rs/Default.aspx (preuzeto 17. 8. 2016).

37. COBISS/SciMet za spremljanje znanstvene produkcije slovenskih avtorjev. http://scimet.izum.si/ (preuzeto 26. 3. 2017).

\title{
Publicly Available Bibliographies of Serbian Researchers - Conditions and Perspectives
}

\begin{abstract}
The bibliographies of Serbian researchers are a valuable source of information about the local research outputs. They also play an important role in the system of evaluation of scientific results of individuals, project teams and scientific institutions. In Serbia there is no nationwide uniform platform that would enable a full insight into bibliographic information about the publications of currently active researchers. This paper provides a historical overview of bibliographic tracking of the research outputs in Serbia. It presents earlier bibliographic databases and various modern electronic services that index scientific publications of Serbian researchers. Through an analysis of the advantages and shortcomings of these sources of information, the author comes to the conclusion that in Serbian libraries there are various bibliographic databases which are not integrated and interoperable. The solution to this problem can be found in the inclusion of all the libraries in E-CRIS (Electronic Current Research Information System) or compiling bibliographies of the researchers using ORCID (Open Researcher and Contributor ID).
\end{abstract}

Keywords: researchers, Serbia, bibliographies, electronic databases and services, E-CRIS, digital repositories, ORCID 